\title{
PENGEMBANGAN MODEL PERMAINAN SEPAKTAKRAW SEBAGAI PEMBELAJARAN PENDIDIKAN JASMANI
}

\author{
Nur Moh Kusuma Atmaja ${ }^{1}$, Kurnia Dyah Anggorowati ${ }^{2}$ \\ ${ }^{1,2}$ Dosen STKIP Melawi \\ Jl. RSUD Melawi km. 04 Kec. Nanga Pinoh Kab. Melawi Kalimantan Barat \\ E-mail: nur_atmaja@yahoo.co.id, kurniadyah12@yahoo.com
}

\begin{abstract}
The research aims to (1) produce models of sepaktakraw games in physical education learning that are suitable for upper class elementary school students; (2) Knowing the effectiveness of the sepaktakraw game model developed in the physical education learning program that is suitable for upper class elementary school students. This research method uses Development Research (Research And Development) through 10 stages The results of the research are the development of the sepaktakraw game model consisting of 10 types of games which are grouped into five categories based on the basic techniques of play namely kicking, defending, servicing, smash, and games. The game model: (1) kicking techniques: game (bola apung, bola jinak, bola bomerang and bolan); (2) defense techniques: game (ombak bola, bolarus, and bosi); (3) service techniques: bolvis game; (4) smash techniques: bomes game; and (5) based on the game: bola vokra game.
\end{abstract}

Keywords: model, sepaktakraw game, elementary school.

\begin{abstract}
Abstrak:Penelitian ini bertujuan untuk (1) menghasilkan model permainan sepaktakraw dalam pembelajaran pendidikan jasmani yang sesuai untuk siswa sekolah dasar kelas atas; (2) Mengetahui keefektifan model pengembangan permainan sepaktakraw sebagai pembelajaran pendidikan jasmani untuk siswa sekolah dasar kelas atas. Metode penelitian ini menggunakan Penelitian Pengembangan (Research And Development) melalui 10 tahap. Hasil penelitian ini adalah pengembangan model permainan sepaktakraw yang terdiri dari 10 jenis permainan yang dikelompokkan menjadi 5 kategori teknik dasar bermain yaitu sepakan, bertahan, servis, smas, dan game. Model permainan: (1) teknik sepakan: permainan (bola apung, bola jinak, bola bomerang dan bolan); (2) teknik bertahan: permainan (ombak bola, bolarus, dan bosi); (3) teknik servis: permainan bolvis; (4) teknik smash: permainan bomes; dan (5) game: permainan bola vokra.

Kata kunci: model, permainan sepaktakraw, sekolah dasar.
\end{abstract}

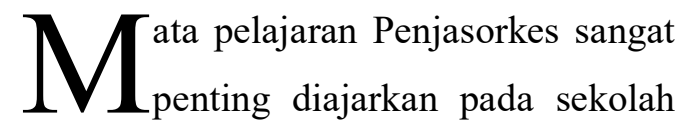
dasar. Penjasorkes merupakan bagian integral dari pendidikan secara keseluruhan yang memiliki peranan dalam membina pertumbuhan fisik, pengembangan psikis, keterampilan motorik, pengetahuan dan penghayatan 
nilai-nilai serta pembentukan pola hidup yang sehat. Tujuan Penjasorkes di sekolah dasar juga mempertimbangkan adanya tujuan pembelajaran, kemampuan siswa, metode pembelajaran, materi, sarana dan prasarana, serta aktifitas pembelajaran.

Materi ajar dalam Penjasorkes mempunyai beberapa aspek diantaranya aspek permainan, aspek pengembangan, aspek uji diri/senam, aspek ritmik, aspek akuatik, dan aspek kesehatan. Aspek permainan mempunyai persentase terbesar daripada aspek materi ajar lainnya. Permainan mengajarkan nilainilai yang terdiri dari nilai kerjasama, sportivitas, kejujuran, toleransi, dan percaya diri. Permainan dan olahraga meliputi permainan bola kecil dan permainan bola besar. Permainan bola kecil yang diajarkan diantaranya kasti, rounders, softball, dan baseball. Sedangkan permainan bola besar yang diajarkan diantaranya sepak bola, bola voli, dan bola basket. Materi permainan dan olahraga diajarkan pada kelas atas atau kelas 4, 5, dan 6. Permainan olahraga yang diajarkan tidak hanya sebatas yang tercantum dalam kurikulum penjasorkes saja, melainkan banyak materi permainan lainnya yang bisa diajarkan. Permainan olahraga lainnya yaitu olahraga tradisional, permainan eksplorasi gerak, tenis meja, bulutangkis, bola tangan, sepaktakraw, tonis, dan aktivitas lainnya.

Materi permainan olahraga sepaktakraw tidak secara jelas tercantum dalam kurikulum, akan tetapi masih termasuk dalam lingkup permainan bola kecil. Permainan sepaktakraw masih menjadi olahraga pilihan di dalam kurikulum penjasorkes sehingga sangat jarang diajarkan di sekolah dasar. Permainan sepaktakraw sangat baik untuk diajarkan dan dikembangkan di sekolah dasar. Sepaktakraw sangat cocok untuk mencapai tujuan pembelajaran di sekolah yaitu meningkatkan pertumbuhan baik secara fisik maupun psikis.

Permainan sepaktakraw merupakan permainan netgames yang dilakukan secara beregu. Permainan sepaktakraw tidak memerlukan lapangan yang luas serta peralatan yang rumit. Lapangan yang digunakan hanya seluas 13,4 meter x 6,1 meter dan menggunakan bola berbahan dasar rotan atau fiber. Penggunan lapangan yang tidak terlalu luas dalam permainan sepaktakraw sangat tepat untuk menunjang pembelajaran dan materi permainan yang diajarkan di sekolah dasar. Sekolah dasar rata-rata hanya memiliki lapangan olahraga yang sempit. 
Permainan sepaktakraw akan dapat memberi tantangan kepada para siswa di sekolah dasar untuk bermain. Akan tetapi, permainan sepaktakraw sangat jarang dan bahkan belum dikenalkan atau diajarkan oleh guru penjaskes. Hanya beberapa sekolah dasar saja yang telah mengajarkan sepaktakraw kepada anak. Guru penjaskes lebih memilih permainan lainnya seperti kasti, rounders, bola bakar, bulutangkis, dan lain-lain sebagai pembelajaran permainan bola kecil. Permainan sepaktakraw sebagai permainan bola kecil harusnya dapat diajarkan kepada anak. Keterbatasan keterampilan dan pengetahuan guru akan permainan sepaktakraw menjadi salah satu alasan permainan sepaktakraw belum diajarkan di sekolah dasar. Para guru menganggap sepaktakraw sebagai permainan yang sulit dilakukan. Oleh karena itu, pengetahuan siswa terhadap permainan sepaktakraw sangatlah minim dan bahkan tidak tahu. Siswa tidak mengenal permainan sepaktakraw karena tidak pernah melihat ataupun memainkannya.

Lumintuarso (2013: 8-9) berpendapat bahwa sepak takraw yang diajarkan di sekolah dasar dapat dijadikan sebagai pembinaan multilateral anak. Pembinaan multilateral anak meliputi pengembangan ketrampilan gerak, pengembangan kemampuan fisik, dan pengembangan mental sosial. Permainan sepaktakraw yang diajarkan diharapkan dapat memberikan pengembangan ketrampilan gerak khususnya gerak dasar bermain sepak takraw, mengembangakan kebugaran jasmani anak dan mengembangkan mental sosial anak saat bermain permainan sepak takraw.

Materi permainan sepaktakraw seharusnya diajarkan sebagai sarana dalam proses pendidikan yang disesuaikan dengan tumbuh kembang anak usia sekolah dasar. Materi yang diajarkan tidak menyulitkan dan memberatkan anak, karena anak usia sekolah dasar masih berada pada tahapan anak untuk bermain. Melalui bermain yang dirasakan anak adalah kesenangan dan kegembiraan tanpa memikirkan hasil akhir. Dengan bermain, secara tidak langsung anak akan mengenal karakteristik permainan yang diajarkan serta dapat berinteraksi secara baik dengan teman sepermainannya. Interaksi tersebut akan memotivasi anak untuk bergerak secara aktif sehingga aspek psikomotor, afektif dan kognitif anak juga ikut berkembang.

Mengenalkan dan mengembangkan permainan sepaktakraw di sekolah dasar maka perlu membuat pengembangan 
dengan memodifikasi permainan sesuai dengan tingkat pertumbuhan dan perkembangan anak. Hal ini dimaksudkan agar anak lebih siap secara fisik dan psikis dalam menerima permainan tersebut. Pengembangan harus memperhatikan kesempatan dan layanan yang sama bagi setiap anak dalam permainan tersebut. Pengembangan permainan sepaktakraw juga harus memperhatikan keterampilan dasar dominan yang dipandang dapat mendukung pencapaian keberhasilan dalam memainkan teknik-teknik dasar sepaktakraw. Keterampilan dasar dominan dalam bermain antara lain keterampilan lokomotor, keterampilan nonlokomotor, dan keterampilan manipulatif. Pengembangan permainan sepaktakraw harus memperhatikan prinsip penyesuaian dalam modifikasi permainan. Penyesuaian merujuk pada aspek fisik (tinggi tubuh dan ukuran anggota badan) dan kemampuan anak atau siswa, karena yang diutamakan adalah proses dan dampak pedogogik, bukan kepada hasil akhir. Modifikasi permainan berupa perubahan ukuran, bentuk, dan bahan dari alat yang digunakan, perubahan ukuran lapangan dan tinggi net, serta peraturan permainan yang lebih jelas dan sederhana.
Esensi dari modifikasi permainan sepaktakraw adalah untuk memudahkan siswa menguasai teknik dasar dan memperoh pengalaman sukses tanpa ada rasa bosan, jenuh, dan keluhan lelah saat melakukan permainan. Modifikasi permainan diharapkan dapat memberi kesempatan yang sama bagi semua siswa, sehingga permainan tidak hanya dimonopoli oleh para siswa yang lebih mampu. Berdasarkan uraian di atas, diperlukan pengembangan model permainan sepaktakraw sebagai pembelajaran pendidikan jasmani bagi anak sekolah dasar kelas atas.

\section{METODE PENELITIAN}

Penelitian ini menggunakan penelitian pengembangan atau dikenal dengan Research and Development (R\&D). Langkah-langkah dalam penelitian pengembangan atau Research and Development (R\&D) yang digunakan dalam penelitian ini adalah adaptasi model pengembangan (Borg \& Gall, 2007: 590) dan model pengembangan (Sugiyono, 2010: 407). pengembangan dilaksanakan untuk mendapatkan model-model permainan sepak takraw sebagai pembelaaran pendidikan jasmani bagi anak sekolah dasar kelas atas di kabupaten Melawi yang disesuaikan dengan tahap-tahap perkembangan dan karakteristik siswa. 
Uji coba dilakukan dengan tujuan untuk menyempurnakan model permainan dengan mempraktikkan secara langsung di lapangan. Uji coba produk dilakukan sebanyak du akali yaitu uji coba skala kecil dan uji coba skala besar. Draf model sebelum diujicobakan di lapangan, di mintakan validasi terlebih dahulu kepada ahli materi yang telah ditunjuk. Pada tahap validasi, para ahli materi juga akan memeberikan penelitian terhadap draf model yang telah disusun sehingga dapat diketahui apakah model yang disusun layak untuk diujicobakan di lapangan. Peran ahli materi dalam tahap uji ciba di lapangan adalah sebagai observer untuk mengobservasi kelayakan draf model yang telah disusun dengan kenyataan di lapangan. Setelah proses uji coba lapangan baik skala kecil dan skala besar dilakukan, akan dihasilkan modep permainan yang benar-benar valid.

Subjek coba dalam penelitian ini dalah siswa sekolah dasar kelas atas. Sesuai dengan tahapan penelitian, dilaksanakan beberapa tahapan proses pengambilan data. Proses pengambilan data dilakukan dengan uji coba lapangan skala kecil dan skala besar. Uji coba skala kecil melibatkan siswa SDN 03 Nanga Pinoh sebanyak 28 siswa. Ui coba skala besar melibatkan siswa dari SDN 06 Nanga Pinoh, SDN 13 Nanga Pinoh dan SDN 03 Nanga Pinoh sebanyak 78 siswa.

Ada 10 langkah yang digunakan sebagai langkah pengembangan model pembelajaran permainan sepaktakraw bagi siswa kelas atas Sekolah Dasar dalam penelitian ini. Langkah-langkah tersebut adalah sebagai berikut: (1) Penelitian Pendahuluan; (2) Perencanaan;

(3) Produk Awal; (4) Validasi Desain;

(5) Revisi Desain; (6) Ujicoba produk;

(7) Revisi Desain; (8) Uji coba produk;

(9) Revisi Produk; (10) Diseminasi Produk.

\section{Prosedur Pengembangan}

Hal yang perlu dilakukan sebelum menghasilkan produk adalah prosedur pengembangan. Prosedur pengembangan yang dilakukan dalam penelitian pengembangan ini yaitu prosedur pengembangan produk. Menurut Borg and Gall prosedur pengembangan dikelompokkan ke dalam empat tahap pengembangan yang meliputi: (1) studi pendahuluan, (2) pengembangan, (3) uji lapangan, dan (4) diseminasi produk.

Pertama: studi pendahuluan, meliputi: (a) Observasi dan wawancara terhadap guru penjasorkes di SDN 03 Nanga Pinoh, SDN 13 Nanga Pinoh dan SDN 06 Nanga Pinoh, studi pustaka, mengkaji teori dan hasil-hasil penelitian 
yang relevan dengan penelitian yang dilakukan dan (2) studi lapangan, melakukan survei, mengkaji karakter subjek penelitian, dan melihat kemungkinan-kemungkinan jika produk penelitian yang berupa modul pembelajaran diterapkan.

Kedua: pengembangan, meliputi: (a) Analisis tujuan, merumuskan tujuan yang ingin dicapai dari penelitian pengembangan yang akan dilakukan, dalam hal ini tujuan berhubungan dengan permainan sepaktakraw. (b) Analisis kemampuan, memprediksi dana, tenaga, dan waktu yang dibutuhkan dalam melakukan penelitian. (c) Prosedur pengembangan (pengembangan desain), membuat desain produk yang akan dikembangkan, menentukan sarana dan perasarana penelitian yang akan digunakan, dan menentukan tahap-tahap pelaksanaan uji desain di lapangan. (d) Validasi ahli, melakukan validasi dengan melibatkan para ahli dan untuk mengetahui apakah model permainan yang dikembangkan dalam penelitian ini siap dilakukan uji lapangan. Ahli materi melibatkan dua orang adalah Nur Sulistyo Mutaqin, M.Or dan Endri Triyadi, A.Md sebagai ahli dalam bidang permainan sepak takraw, dan yang ketiga adalah Perawati Anglis, S.Pd sebagai praktisi pendidikan jasmani dan kesehatan.

Ketiga: uji lapangan, meliputi: (a) Uji lapangan skala kecil: Merupakan uji lapangan awal yang melibatkan siswa kelas atas salah satu SDN di Kabupaten Melawi yaitu SDN 03 Nanga Pinoh sebanyak 28 siswa. Setelah dilakukan uji lapangan skala kecil, maka dilakukan revisi terhadap model permainan yang dikembangkan dapat layak untuk diuji kembali pada uji lapangan yang lebih luas. (b) Uji lapangan skala luas: Merupakan uji lapangan dengan jumlah subjek yang lebih banyak daripada ujicoba lapangan skala kecil dengan melibatkan siswa kelas atas dari tiga SDN di Kabupaten Melawi yaitu SDN 06 Nanga Pinoh, SDN 13 Nanga Pinoh dan SDN 03 Nanga Pinoh sebanyak 78 siswa.

Keempat: (a) Diseminasi, dilaksanakan dengan membuat laporan hasil pengembangan untuk diajukan dalam hasil dari penelitian dosen pemula. (b) Sosialisasi produk akhir, dilakukan dengan memberikan produk yang telah dikembangkan kepada salah satu lembaga pendidikan dasar.

\section{Desain Uji Coba}

Draf model permainan sepaktkraw disusun secara tertulis kemudian dipraktikan. Dokumentasi praktikum model permainan sepaktakraw digunakan 
untuk membantu para ahli dan guru dalam memahami pelaksanaan draf model. Para ahli memberikan masukan perbaikan draf dan penilaian. Peneliti melakukan revisi draf dan hasil revisi disampaikan pada validator untuk mendapatkan validasi. Kegiatan selanjutnya adalah pelaksanaan uji coba produk di lapangan. Uji coba produk dilakukan sebanyak dua kali, terdiri dari uji coba dengan skala kecil dan skala besar. Guru berperan sebagai pelaksana proses pembelajaran sesuai dengan draf model. Uji coba yang telah dilakukan akan diobservasi oleh observer yang terdiri dari para ahli materi dan guru Penjaskes untuk mengetahui kelayakan model permainan sepaktakraw yang telah disusun dengan kenyataan hasil uji coba.

\section{Subjek Uji Coba}

Subjek dalam penelitian pengembangan ini yaitu: (1) siswa kelas atas disalah satu Sekolah Dasar Negeri dan/atau Swasta di Kabupaten Melawi untuk ujicoba skala kecil, dan (2) siswa kelas atas di tiga Sekolah Dasar Negeri dan/atau Swasta di Kabupaten Melawi.

\section{Jenis Data}

Data yang dikumpulkan dari penelitian ini ada dua jenis, yaitu data kualitatif dan kuantitatif. Data kualitiatif diperoleh dari: (1) data saran perbaikan draf model awal dan (2) hasil observasi observer pada pelaksanaan uji coba dengan skala kecil dan besar. Data kuantitatif diperoleh dari: (1) penilaian skala nilai validasi; (2) penilaian pada skala nilai observasi pelaksanaan permainan; dan (3) penilaian skala nilai observasi keefektifan pelaksanaan model dalam pembelajaran.

\section{Instrumen Pengumpulan Data}

Instrumen pengumupulan data yang digunakan berupa angket skala nilai. Angket berisi daftar pernyataan disertai skala nilai digunakan untuk memberikan penilaian pada draf model permainan, observasi pelaksanaan uji coba skala kecil dan besar. Angket dalam pelaksanaan uji coba dengan skala kecil dan besar terdiri dari dua macam, yaitu observasi pelaksanaan model dan keefektifan model dalam proses pembelajaran.

\section{Teknik Analisis Data}

Teknik analisis data yang dilakukan dalam penelitian ini yaitu analisis deskriptif kuantitatif dan analisis deskriptif kualitatif. Analisis deskriptif kuantitatif dilakukan untuk menganalisis data-data berikut: (1) data skala nilai hasil penilaian para ahli materi terhadap draf model permainan sepaktakraw sebelum pelaksanaan uji coba di lapangan, (2) data hasil observasi para 
ahli materi terhadap model permainan sepaktakraw, dan (3) data hasil observasi para ahli materi terhadap keefektifan model permainan sepaktakraw. Sementara analisis deskriptif kualitatif dilakukan terhadap: (1) data kekurangan dan masukan terhadap draf model permainan sepaktakraw, dan (2) data kekurangan dan masukan terhadap model permainan sepaktakraw pada skala kecil dan besar.

Draf awal permainan sepaktakraw dianggap layak untuk diujicobakan dalam skala kecil apabila para ahli telah memberi validasi dan menyatakan bahwa semua item klasifikasi dalam skala nilai dinilai "ya" dengan cara memberi tanda centang $(\sqrt{ })$ pada kolom ya. Dalam hal ini terdapat dua jenis nilai, yaitu hasil penilaian "ya" mendapat nilai (1) dan hasil penilaian "tidak" mendapat nilai nol (0). Jika terdapat ahli materi yang berpendapat bahwa item klasifikasi tidak (nilai nol), maka dilakukan pengkajian ulang terhadap model permainan yang dapat ditindaklanjuti dengan proses revisi.

Data hasil observasi para ahli materi terhadap model permainan, hasil observasi "ya" mendapat nilai satu (1) dan hasil observasi "tidak" mendapat nilai nol (0). Hasil penilaian terhadap item-item observasi dijumlahkan, lalu total nilainya dikonversikan untuk mengetahui kategorinya. Pengkonversian nilai dilakukan dengan mengikuti standar Penilaian Acuan Patokan (PAP). Dalam menginterpretasikan skor mentah menjadi nilai dengan menggunakan pendekatan PAP, terlebih dahulu ditentukan kriteria nilai dan batasbatasnya, yang akan dipaparkan berikut ini:

Tabel 1. Pedoman Konversi Nilai PAP

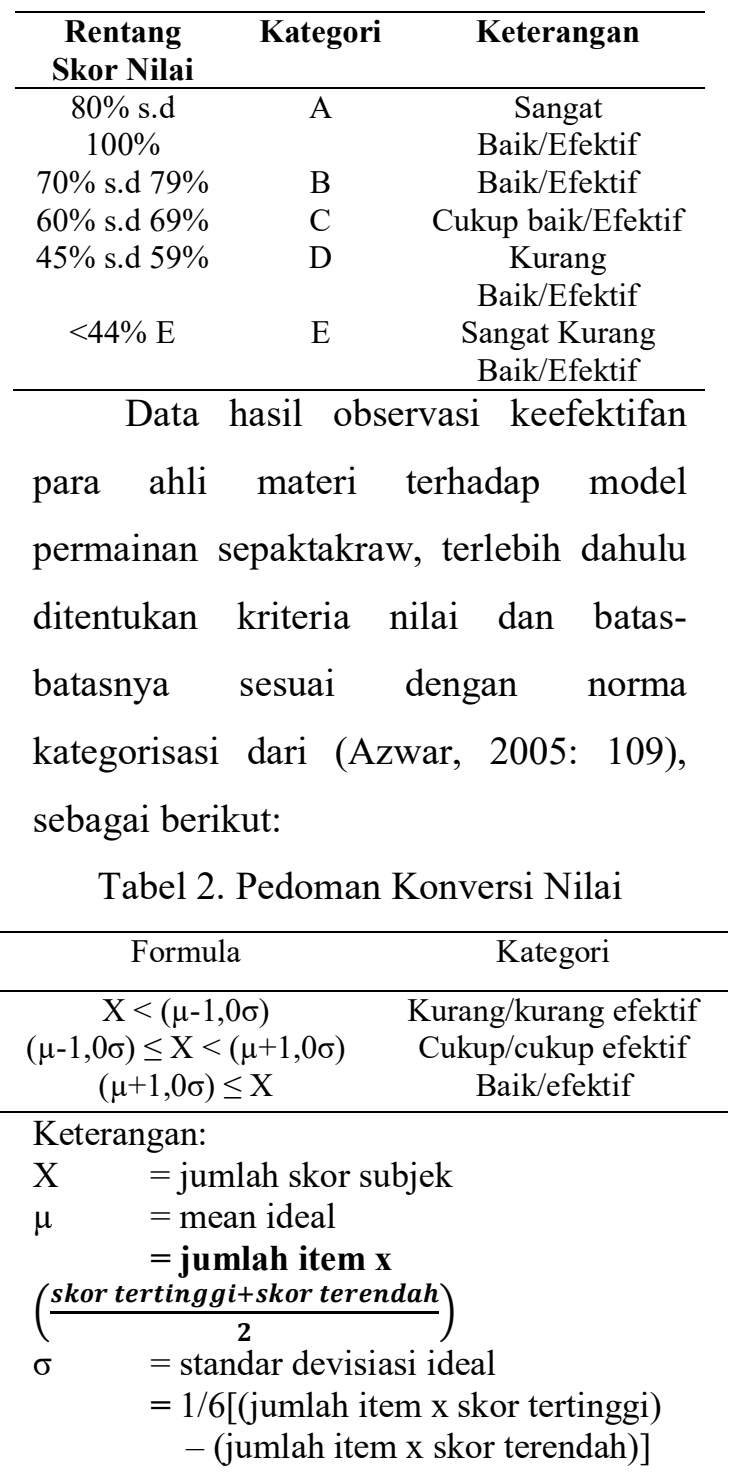


Teknik analisis data kualitatif dalam penelitian ini dilakukan bersamaan dengan pengumpulan data. Proses analisis data dilakukan dengan mereduksi data yaitu proses penyelesaian, penyederhanaan, pemfokusan, pengabstraksian dan penstarnsformasian data (Arikunto, 2010: 29). Reduksi data dilakukan secara berkesinambungan mulai awal pengumpulan data sampai selesai. Setalah melakukan reduksi data, aktivitas analisis data selanjutnya adalah penyajian data dan membuat kesimpulan data. Data kualitatif pada studi pendahuluan berupa hasil wawancara dan catatan lapangan direduksi, disajikan untuk diberikan makna, dan akhir disimpulkan untuk memperjelas maslah yang ada. Hal tersebut dilakukan untuk memperkuat latar belakang masalah penelitian. Pada proses pengembangan produk, data berupa masukan, saran perbaikan dari pendapat observer direduksi, disajikan, kemudian dianalisis untuk mengambil kesimpulan sebagai bahan revisi.

\section{HASIL PENELITIAN}

\section{Data Validasi Draf Produk Awal}

Penilaian skala nilai terhadap revisi draf awal model permainan sepak takraw sebelum diujicobakan di lapangan divalidasikan kepada para ahli materi yaitu: (1) ahli permainanan sepak takraw dan (2) ahli pembelajaran pendidikan jasmani. Para ahli berpendapat bahwa pengembangan model permainan sepak takraw sebagai pembelajaran pendidikan jasmani bagi anak sekaolah dasar yang terdiri atas 10 jenis permainan yang dikelompokkan menjadi lima kategori berdasarkan teknik dasar bermain yaitu teknik sepakan, bertahan, servis, smas, dan game telah memenuhi persyaratan kelayakan untuk diujicobakan di lapangan. Penghitungan ini menjadi dasar bahwa darf awal model permainan sepak takraw sebagai pembelajran pendidikan jasmani bagi anak sekolah dasar kelas atas adalah layak untuk uji coba skala kecil.

\section{Data Uji Coba Skala Kecil}

Uji coba skala kecil dilakukan pada anak kelas atas SD N 03 Nanga Pinoh dengan jumlah 28 anak. Pelaksanaan uji coba skala kecil di dokumentasikan dan dibuat draf materi beserta gambar dan aturan bermainnya kemudian diobservasikan oleh observer (ahli olahraga sepak takraw, ahli pembelajaran pendidikan jasmani, dan guru penjasorkes sekolah dasar). Data yang diperoleh dari observer berupa: (1) data hasil observasi pelaksanaan model permainan sepak takraw, (2) data hasil observasi keefektifan model sepak takraw dan (3) saran perbaikan dari para 
ahli dan praktisi. Model permainan sepak takraw terdiri atas 10 jenis permainan yang dikatagorikan menjadi 5 kategori berdasarkan teknik dasar bermain yaitu teknik sepakan, teknik bertahan, servis, smas, dan permainan (game).

Hasil Penilaian Observasi Para Ahli Materi

Penilaian observasi dilakukan para ahli materi pada uji coba skala kecil terhadap pengembangan model sepak takraw yang terdiri 10 jenis permainan yang dikategorikan menjadi 5 kategori berdasarkan teknik dasar. Hasil total nilai para ahli materi untuk 10 permainan semua sama yaitu sebesar 15 terletak pada interval $10 \leq \mathrm{X}$. Jadi penilaian observasi para ahli materi pada uji coba skala kecil berkategori baik.

\section{Hasil Penilaian Obaservasi}

\section{Keefektifan Para Ahli Materi}

Penilaian obaservasi Keefektifan dilakukan para ahli materi pada uji coba skala kecil terhadap pengembangan model sepak takraw yang terdiri 10 jenis permainan yang dikategorikan menjadi 5 kategori berdasarkan teknik dasar. Hasil total nilai para ahli materi untuk 10 permainan yaitu terletak pada interval 30 $<$ X. Jadi penilaian observasi para ahli materi pada uji coba skla kecil berkategori efektif.

\section{Data Kuesioner Siswa}

Hasil kuesioner siswa terhadap pengembangan model permainan sepak takraw yang terdiri dari 10 jenis permainan dikategorikan 5 kategori berdasarkan teknik dasar bermain yaitu teknik sepakan, teknik bertahan, servis, smas dan permainan (game), menunjukkan bahwa respon dari anak yang menjadi sampel dari uji coba skala kecil, secara umum memberikan respon yang positif terhadap seluruh pengembangan model permainan sepak takraw sebagai pembelajaran pendidikan jasmani bagi anak sekolah dasar kelas atas.

\section{Data Masukan dan Saran Ahli Materi}

Adapun masukan dari para ahli terhadap pengembangan model permainan sepaktakraw dapat dianalisis sebagai berikut: (a) Ahli Olahraga Sepaktakraw: Ahli olahraga sepaktakraw memberi masukan terhadap hasil skala kecil yaitu pengarahan dalam melakukan permainan lebih diperjelas dan guru harus lebih optimal dan interaktif dengan siswa dalam proses pembelajaran. Peran guru dalam mengarahkan pada saat proses pembelajran sangat penting dan peran guru dalam permainan harus berperan secara optimal dan interaktif. Peran tersebut dapat membantu anak dalam belajar gerak karena mendapat 
motivasi, semangat, dan contoh dari guru. Anak tidak akan merasa kesulitan dalam mempraktikkan permainan. (b) Ahli Pembelajaran Pendidikan Jasmani: Ahli pembelajaran pendidikan jasmani tidak memberi masukan terhadap hasil skala kecil dikarenakan proses pembelajaran melalui pengembangan model permainan sepaktakraw sudah efektif dilaksanakan. (c) Guru Penjasorkes: Guru penjasorkes memberi masukan terhadap hasil skala kecil yaitu dalam melakukan permainan jarak antara siswa agak diperlebar supaya tidak tabrakan dan tertib. Pengaturan jarak, posisi dan formasi anak dalam pembelajaran penjas sangat perlu dilakukan karena setiap anak diharuskan untuk bergerak dan tertib dalam pembelajaran. Untuk itu jarak anak atau kelompok diperlebar menyesuaikan dengan jumlah anak yang ada. Keleluasaan anak dalam bergerak tidak terbatasi oleh jarak yang sempit.

\section{Data Uji Coba Skala Besar}

Uji coba skala besar dilakukan di tiga sekolah SDN 06 Nanga Pinoh dengan jumlah siswa 25 anak, SDN 13 Nanga Pinoh dengan jumlah siswa 25 anak dan SDN 03 Nanga Pinoh dengan jumlah siswa 28 anak. Pelaksanaan uji coba skala besar di dokumentasikan dan ditulis materi beserta gambar dan aturan bermainnya kemudian diobservasikan oleh observer (ahli olahraga sepak takraw, ahli pembelajaran pendidikan jasmani, dan guru penjasorkes sekolah dasar). Data yang diperoleh dari observer berupa: (1) data hasil observasi pelaksanaan model permainan sepak takraw, (2) data hasil observasi keefektifan model sepak takraw dan (3) saran perbaikan dari para ahli dan praktisi. Model permainan sepak takraw terdiri atas 10 jenis permainan yang dikatagorikan menjadi 5 kategori berdasarkan teknik dasar bermain yaitu teknik sepakan, teknik bertahan, servis, smas, dan permainan (game).

\section{Hasil Penilaian Observasi Para ahli Materi}

Penilaian observasi dilakukan para ahli materi pada uji coba skala besar terhadap pengembangan model sepak takraw yang terdiri 10 jenis permainan yang dikategorikan menjadi 5 kategori berdasarkan teknik dasar. Hasil total nilai para ahli materi untuk 10 permainan semua sama yaitu sebesar 15 terletak pada interval $10 \leq \mathrm{X}$. Jadi penilaian observasi para ahli materi pada uji coba skala kecil berkategori baik.

\section{Hasil Penilaian Observasi Keefektifan Para Ahli Materi \\ Penilaian obaservasi Keefektifan dilakukan para ahli materi pada uji coba}


skala besar terhadap pengembangan model sepak takraw yang terdiri 10 jenis permainan yang dikategorikan menjadi 5 kategori berdasarkan teknik dasar. Hasil total nilai para ahli materi untuk 10 permainan yaitu terletak pada interval 30 $\leq \mathrm{X}$. Jadi penilaian observasi para ahli materi pada uji coba skla kecil berkategori efektif.

\section{Hasil Kuesioner Siswa}

Hasil kuesioner siswa terhadap pengembangan model permainan sepak takraw yang terdiri dari 10 jenis permainan dikategorikan 5 kategori berdasarkan teknik dasar bermain yaitu teknik sepakan, teknik bertahan, servis, smas dan permainan (game), menunjukkan bahwa respon dari anak yang menjadi sampel dari uji coba skala besar, secara umum memberikan respon yang positif terhadap seluruh pengembangan model permainan sepak takraw sebagai pembelajaran pendidikan jasmani bagi anak sekolah dasar kelas atas.

\section{Data Masukan dan Saran Ahli Materi}

Para ahli materi menilai tidak ada kekurangan dan masukan dalam pengembangan model permaianan sepak takraw pada uji coba skala besar. Masukan, kekurangan dan saran yang diberikan oleh para ahli materi pada saat uji coba skala kecil benar-benar dibenahi dan diterapkan dalam uji coba skala besar sehingga kekurangan, masukan dan saran dapat terpenuhi dengan baik. Para ahli materi setuju dengan pengembangan model permainan sepak takraw yang dibuat pada skal besar sehingga dapat disetujui untuk dijadikan produk final.

\section{Kajian Produk Akhir}

Setelah mendapatakan penilaian dan masukan dari semua ahli materi, dilakukan revisi terhadap draf model pengembangan permainan sepak takraw sebagai pembelajaran pendidikan jasmani bagi anak sekolah dasar kelas atas di kabuoaten Melawi. Dari hasil penilaian, masukan dan saran dan proses revisi dihasilkan pengembangan model permainan sepak takraw sebagai pembelajaran pendidikan jasmani bagi anak sekolah dasar kelas atas yang tertuang dalam bentuk buku/modul panduan berjudul "Permainan Sepak Takraw bagi siswa kelas atas sekolah dasar" yang layak digunakan.

\section{SIMPULAN}

Berdasarkan hasil penelitian yang telah diuraikan pada bagian pembahasan, maka dapat diambil kesimpulan sebagai berikut: Pertama, bahwa pengembangan model permainan sepaktakraw sebagai pembelajaran pendidikan jasmani bagi anak sekolah dasar kelas atas terdiri dari 10 permainan yaitu: (1) permainan bola 
apung, (2) permainan bola jinak, (3)

permainan bola boomerang, (4) permainan bomes, (5) permainan ombak bola, (6) permainan bolan, (7) permainan bolarus, (8) permainan bosi, (9) permainan bolvis, dan (10) permainan bola vokra.

Kedua, pengembangan model permainan sepaktakraw disesuaikan dengan standar kompetensi dan kompetensi dasar mata pelajaran penjasorkes sekolah dasar kelas atas yang termuat dalam kurikulum.

Ketiga, pengembangan model permainan sepaktakraw disesuaikan dengan pertumbuhan dan perkembangan anak sekolah dasar kelas atas, disesuaikan dengan gerak dasar permainan sepaktakraw.

Keempat, pengembangan model permainan sepaktakraw disesuaikan dengan kemudahan dan peralatan yang digunakan dalam permainan serta disesuaikan dengan tingkat keamanan pelaksanaan model permainan bagi anak sekolah dasar kelas atas.

Kelima, Pengembangan model permainan sepaktakraw yang dibuat juga layak digunakan untuk pembelajaran bola kecil yakni materi permainan sepaktakraw. Uji kelayakan dilakukan berdasarkan penilaian dari para ahli materi, dan guru penjasorkes sekolah dasar. Penilaian para ahli menunjukkan bahwa pengembangan model permainan sepaktakraw yang disusun layak digunakan sebagai pembelajaran bola kecil yaitu materi permainan sepaktakraw pada siswa sekolah dasar kelas atas.

\section{DAFTAR PUSTAKA}

Arikunto, S. 2003. Prosedur Pneleitian: Suatu Pendekatan Praktik. Jakarta: Rineka Cipta.

Azwar, S. 2005. Penyusunan Skala Psikologi. Yogyakarta: Pustaka Pelajar.

Borg W. R., Gall J.P, \& Gall M.D. 2007. Education Research: An Introduction ( $7^{\text {th }}$ ed.). Boston: Pearson Inc.

Lumintuarso, R. 2013. Pembinaan multilateral bagi atlet pemula (Pedoman latihan dasar bagi atlet muda berbakat). Yogyakarta: UNY Pres.

Sugiyono. 2010. Metode Penelitian Pendidikan. Pendekatan Kualitatif, Kuantatif dan R\&D. Bandung: Alfabeta. 